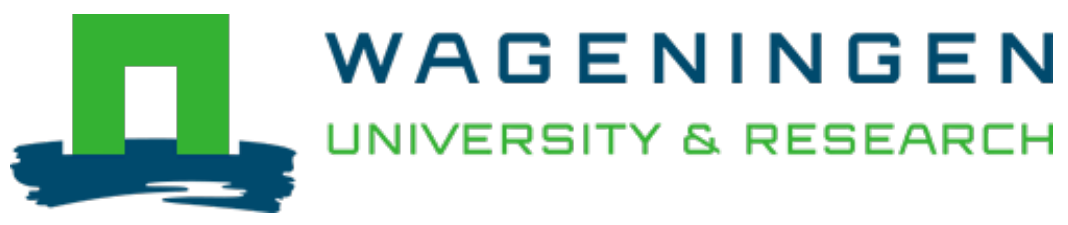

\title{
Effects of metals on activity and community of sulfate-reducing bacterial enrichments and the discovery of a new heavy metal-resistant SRB from Santos Port sediment (São Paulo, Brazil)
}

Environmental Science and Pollution Research

Zampieri, Bruna Del Busso; Nogueira, Elis Watanabe; Oliveira, Ana Julia Fernandes Cardoso; SánchezAndrea, Irene; Brucha, Gunther

https://doi.org/10.1007/s11356-021-15418-9

This article is made publicly available in the institutional repository of Wageningen University and Research, under the terms of article $25 \mathrm{fa}$ of the Dutch Copyright Act, also known as the Amendment Taverne. This has been done with explicit consent by the author.

Article $25 \mathrm{fa}$ states that the author of a short scientific work funded either wholly or partially by Dutch public funds is entitled to make that work publicly available for no consideration following a reasonable period of time after the work was first published, provided that clear reference is made to the source of the first publication of the work.

This publication is distributed under The Association of Universities in the Netherlands (VSNU) 'Article $25 \mathrm{fa}$ implementation' project. In this project research outputs of researchers employed by Dutch Universities that comply with the legal requirements of Article $25 \mathrm{fa}$ of the Dutch Copyright Act are distributed online and free of cost or other barriers in institutional repositories. Research outputs are distributed six months after their first online publication in the original published version and with proper attribution to the source of the original publication.

You are permitted to download and use the publication for personal purposes. All rights remain with the author(s) and / or copyright owner(s) of this work. Any use of the publication or parts of it other than authorised under article $25 \mathrm{fa}$ of the Dutch Copyright act is prohibited. Wageningen University \& Research and the author(s) of this publication shall not be held responsible or liable for any damages resulting from your (re)use of this publication.

For questions regarding the public availability of this article please contact openscience.library@wur.nl 


\title{
Effects of metals on activity and community of sulfate-reducing bacterial enrichments and the discovery of a new heavy metal-resistant SRB from Santos Port sediment (São Paulo, Brazil)
}

\author{
Bruna Del Busso Zampieri ${ }^{1}$ - Elis Watanabe Nogueira ${ }^{2}$ - Ana Julia Fernandes Cardoso de Oliveira ${ }^{3}$. \\ Irene Sánchez-Andrea ${ }^{4}$. Gunther Brucha ${ }^{5}$
}

Received: 18 October 2020 / Accepted: 8 July 2021

(C) The Author(s), under exclusive licence to Springer-Verlag GmbH Germany, part of Springer Nature 2021

\begin{abstract}
Sulfate-reducing bacteria (SRB) can be used to remove metals from wastewater, sewage, and contaminated areas. However, metals can be toxic to this group of bacteria. Sediments from port areas present abundance of SRB and also metal contamination. Their microbial community has been exposed to metals and can be a good inoculum for isolation of metal-resistant SRB. The objective of the study was to analyze how metals influence activity and composition of sulfate-reducing bacteria. Enrichment cultures were prepared with a different metal $(\mathrm{Zn}, \mathrm{Cr}, \mathrm{Cu}$, and $\mathrm{Cd}$ ) range concentration tracking activity of SRB and 16S rRNA sequencing in order to access the community. The SRB activity decreased when there was an increase in the concentration of the metals tested. The highest concentration of metals precipitated were $0.2 \mathrm{mM}$ of $\mathrm{Cd}, 5.4 \mathrm{mM}$ of $\mathrm{Zn}, 4.5 \mathrm{mM}$ of $\mathrm{Cu}$, and $9.6 \mathrm{mM}$ of $\mathrm{Cr}$. The more toxic metals were $\mathrm{Cd}$ and $\mathrm{Cu}$ and had a greater community similarity with less SRB and more fermenters (e.g., Citrobacter and Clostridium). Meanwhile, the enrichments with less toxic metals ( $\mathrm{Cr}$ and $\mathrm{Zn}$ ) had more sequences affiliated to SRB genera (mainly Desulfovibrio). A new Desulfovibrio species was isolated. This type of study can be useful to understand the effects of metals in SRB communities and help to optimize wastewater treatment processes contaminated by metals. The new Desulfovibrio species may be important in future studies on bioremediation of neutral $\mathrm{pH}$ effluents contaminated by metals.
\end{abstract}

Keywords Metals $\cdot$ Desulfovibrio $\cdot$ Sulfate-reducing bacteria $\cdot$ Metal resistance $\cdot$ Bioremediation $\cdot$ Metal removal

Responsible Editor: Robert Duran

Bruna Del Busso Zampieri

brunadbzampieri@gmail.com

Elis Watanabe Nogueira

watanabeelis90@gmail.com

Ana Julia Fernandes Cardoso de Oliveira

ajuliaf@unesp.br

Irene Sánchez-Andrea

irene.sanchezandrea@wur.nl

Gunther Brucha

gunther.brucha@unifal-mg.edu.br

1 Department of Biochemistry and Microbiology, Biosciences, Institute, São Paulo State University - Rio Claro Campus (UNESP IB/RC)), Av. 24 A, 1515, Jardim Vila Bela, Rio Claro, São Paulo 13506-900, Brazil
2 Biological Processes Laboratory, São Carlos School of Engineering, University of São Paulo, Av. João Dagnone, 1100, Santa Angelina, São Carlos, São Paulo 13563-120, Brazil

3 Biosciences Institute, São Paulo State University - São Paulo State's Coast Campus (UNESP IB/CLP), Praça Infante Dom Henrique, s/n Parque Bitaru, São Paulo 11330-900, Brazil

4 Department of Agrotechnology and Food Sciences, Wageningen University and Research, Stippeneng 4, 6708WE, Wageningen, Netherlands

5 School of Technological Sciences, Federal University of Alfenas (UNIFAL-MG), Minas Gerais, Rodovia Aurélio Vilela, n 11.999 Cidade Universitária, Poços de Caldas, Minas Gerais 37715400, Brazil 


\section{Introduction}

Metals are persistent and dangerous contaminants in the environment. Chronic exposure to metals in the environment is a real threat to living organisms, for example metal concentrations above threshold levels (e.g., $\mathrm{Cr} 37.3 \mu \mathrm{g} \mathrm{mg}^{-1}$, Cd $0.6 \mu \mathrm{g}$ $\mathrm{mg}^{-1}, \mathrm{Zn} 123 \mu \mathrm{g} \mathrm{mg}^{-1}$ ) affect the microbiological balance of soils and can reduce their fertility (Wieczorek-Dabrowska et al. 2013; CCME 2002). Another issue is that bioaccumulation of toxic metals in biota of different ecosystems may have adverse effects on animals. Higher levels of metals in biota can have negative effects on the ecological health of aquatic animal species and may contribute to declines in their populations. In the same way, the microbial community is influenced by metal concentrations; high metal levels in the environment can decrease the microbial diversity and their degradation capacity (Ali et al. 2019).

The increase in metal concentrations is most often found near industries and other human activities. The presence of metals in effluents and industries and the lack of proper treatment and disposal contribute to this fact (Masindi and Muedi 2018). Various industries such as mining, chemicals, paper, pesticides, glass, and ceramics contribute to the increase in the concentration of metals found in wastewater and sewage sludge (Sarioglu et al. 2010; Fu and Wang 2011).

Biological sulfate reduction can remove metals from wastewaters, and immobilize metals from soils (e.g., compost). This application is possible due to the difference in the chemical properties of sulfate and sulfite metals. Metals such as cadmium, cobalt, copper, iron, zinc, chromium, and nickel are soluble when in the form of sulfate, but insoluble when in the form of metal sulfide (Paulo et al. 2015). Therefore, sulfide production by sulfate-reducing bacteria (SRB) causes precipitation of metals present in the environment, facilitating their removal (Ayangbenro et al. 2018; Azabou et al. 2007).

SRBs are divided into 7 phylogenetic groups: 5 belong to the Bacteria domain (Deltraproteobacteria, Nitrospirae, Thermodesulfobiaceae, Thermodesulfobacteria, Clostridia); and 2 to the Archaea domain (Euryarchaeota (genus Archeoglobus) and Crenarchaeota (genus Caldivirga and Thermocladium)) (Muyzer and Stams 2008).

This group of anaerobic microorganisms can be found in many anoxic environments, where they use sulfate as the final electron acceptor for the degradation of organic compounds or hydrogen, resulting in sulfide production. The sulfide produced can bind metal ions dissolved, forming metal sulfide (Hu et al. 2020; Muyzer and Stams 2008).

Beside this SRB application, there is a challenge to find an efficient treatment for effluents contaminated with metals using this microbial group (Paulo et al. 2015; Zhang et al. 2016). SRB activity decreases due to the presence of metals in higher concentrations (Bhattacharya et al. 1995). For example, some industrial effluents can have a concentration of 4.6-
17.6 $\mathrm{mM}$ of $\mathrm{Zn}$ and 5.8-22.1 $\mathrm{mM}$ of Cr (Sancey et al. 2011). However, some $\mathrm{Zn}$ and $\mathrm{Cr}$ toxic concentrations, reported in the literature, during the effluent treatment are as follows: $0.85 \mathrm{mM}$ of $\mathrm{Zn}$ and $0.65 \mathrm{mM}$ of $\mathrm{Cr}$ in methanogenic granules (Paulo et al. 2015); $0.22 \mathrm{mM}$ of $\mathrm{Zn}$ and $0.16 \mathrm{mM}$ of $\mathrm{Cr}$ in a sewage sludge digester (Lin 1992); $0.57 \mathrm{mM}$ of $\mathrm{Zn}$ for anaerobic mixed culture (Zayed and Winter 2000); $8.4 \mathrm{mM}$ of $\mathrm{Cr}$ and $12.6 \mathrm{mM}$ of $\mathrm{Zn}$ in acetogenic granules (Paulo et al. 2015). This demonstrates that the presence of metals in sewage can affect the performance of SRB during treatment, since the concentrations found in some effluents are much higher than the concentration which represents toxicity to microorganisms.

However, bacteria, including SRB, can develop resistance through a large diversity of metal resistance genes via both vertical evolution and horizontal gene transfer in order to adapt to the exposure of metal toxicity (Ture et al. 2018; Argudín et al. 2019). Many studies indicate that in contaminated sites, where bacteria were exposed to metal toxicity, the number of resistance genes increases. Moreover, the community in contaminated sites can adapt to metal contamination (Imchen et al. 2018; Guo et al. 2017a; Gillan et al. 2015). Thus, the knowledge about how metals can influence the activity and composition of sulfate-reducing bacteria and which of these SRB can survive in high concentrations of metals can be crucial for the development of bioremediation strategies.

Usually, port areas have metal concentrations above levels considered acceptable by environmental companies (Buruaem et al. 2012). Therefore, in these areas, microbial communities are usually exposed to metal contamination over long periods of time. Allied to this fact, in marine environments, there is a significant abundance and diversity of sulfate-reducing bacteria, since this group is very important in carbon cycling (Jørgensen 1982; Muyzer and Stams 2008).

In this way, in a long-term metal contaminated sediment, microorganisms would present higher resistance to metal toxicity. Thus, there would be greater chances of isolating strains resistant to metals. Selection-resistant SRB is important for enhancing the performance of bioreactors treating metalcontaminated wastes. Thus, the objective of the present work was to analyze, using a long-term metal contaminated sediment from a port area as inoculum, how metals influence the microbial community composition and activity of sulfatereducing bacteria. Besides that, the study also aimed at performing isolation of SRB-resistant strains.

\section{Material and methods}

\section{Study area and sample collection}

The Port of Santos is located in the municipality of Santos, central region of the state of São Paulo coast (Brazil). 
Sediment was collected from 5 stations in the Port of

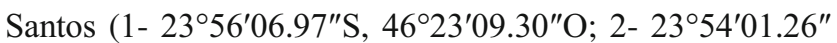
$\mathrm{S}, 46^{\circ} 22^{\prime} 40.10^{\prime \prime} \mathrm{O}$; 3- 23 $3^{\circ} 55^{\prime} 08.48^{\prime \prime} \mathrm{S}, 46^{\circ} 21^{\prime} 11.57^{\prime \prime} \mathrm{O}$; 4$23^{\circ} 55^{\prime} 35.99^{\prime \prime} \mathrm{S}, 46^{\circ} 18^{\prime} 38.69^{\prime \prime} \mathrm{O} ; 5^{-2} 3^{\circ} 58^{\prime} 11.78^{\prime \prime} \mathrm{S}, 46^{\circ} 17^{\prime}$ $\left.38.63^{\prime \prime} \mathrm{O}\right)$ : near industrial effluents or areas proven to be critically contaminated by metals (Pinto et al. 2015; Abessa et al. 2008; Buruaem et al. 2012) (Fig. 1).

\section{Sediment characterization}

Each sampling station was characterized physiochemically using a multi-parameter probe (Horiba U-52G). The parameters measured were $\mathrm{pH}$, salinity, temperature, depth, dissolved oxygen, and conductivity. In the laboratory, sediments were characterized. The percentage of organic matter $(\mathrm{OM})$ content was analyzed through muffle: $20 \mathrm{~g}$ of oven-dried sediment sample $\left(105^{\circ} \mathrm{C} ; 24 \mathrm{~h}\right)$ was placed in a high-form porcelain crucible and set in a muffle furnace for combustion at $600{ }^{\circ} \mathrm{C}$ for $6 \mathrm{~h}$. The organic matter content was determined through the mass difference in relation to the original soil sample (Jiménez and Garcia 1992). The percentage of total organic carbon (TOC) was carried out from oxidation with potassium dichromate and sulfuric acid, and subsequent titration of dichromate over oxidation with ammoniacal ferrous sulfate, as described in Gaudette et al. (1974).
The metal concentration was determined by the SW 846 US EPA 3051 methodology (USEPA 1994), based on an acidic digestion (Navarro et al. 2011). Metals were quantified by inductively coupled plasma atomic emission spectrometry (ICP-AES) (Spectro Arcos, Germany). Analysis was performed by using the operational parameters recommended by the manufacturer: incident power of $1.2 \mathrm{~kW}$; plasma, nebulizer, and auxiliary argon flow rates of 20,1.0, and $1 \mathrm{~L} \mathrm{~min}^{-1}$, respectively, and observation plasma height of $15 \mathrm{~mm}$ above the induction coil (Navarro et al. 2011). Target metals for analysis were $\mathrm{Cr}, \mathrm{Cu}, \mathrm{Zn}$, and $\mathrm{Cd}$ due to their environmental relevance in the area (Pinto et al. 2015; Abessa et al. 2008; Buruaem et al. 2012).

\section{Enrichment set-up and activity track}

First, $45 \mathrm{~mL}$ of Postgate $\mathrm{C}$ medium (Supplementary material) was dispersed in $150 \mathrm{~mL}$ anaerobic bottles and different concentrations of metals were added (Cabrera et al. 2006; Gardner and Stewart 2002; Luptakova and Kusnierova 2005). Lactate was used as electron donor $(60 \mathrm{mM})$ and sulfate was used as electron acceptor $(30 \mathrm{mM})$. Cadmium was used in the form of $\mathrm{CdSO}_{4} \mathrm{xH}_{2} \mathrm{O}$ at different concentrations of $0.2,0.3,0.4$, and $0.5 \mathrm{mM}$. Copper was used in the form of $\mathrm{CuSO}_{4}$ at concentrations of $0.3,1.3,3.0$, and $5 \mathrm{mM}$. Chromium was used in the
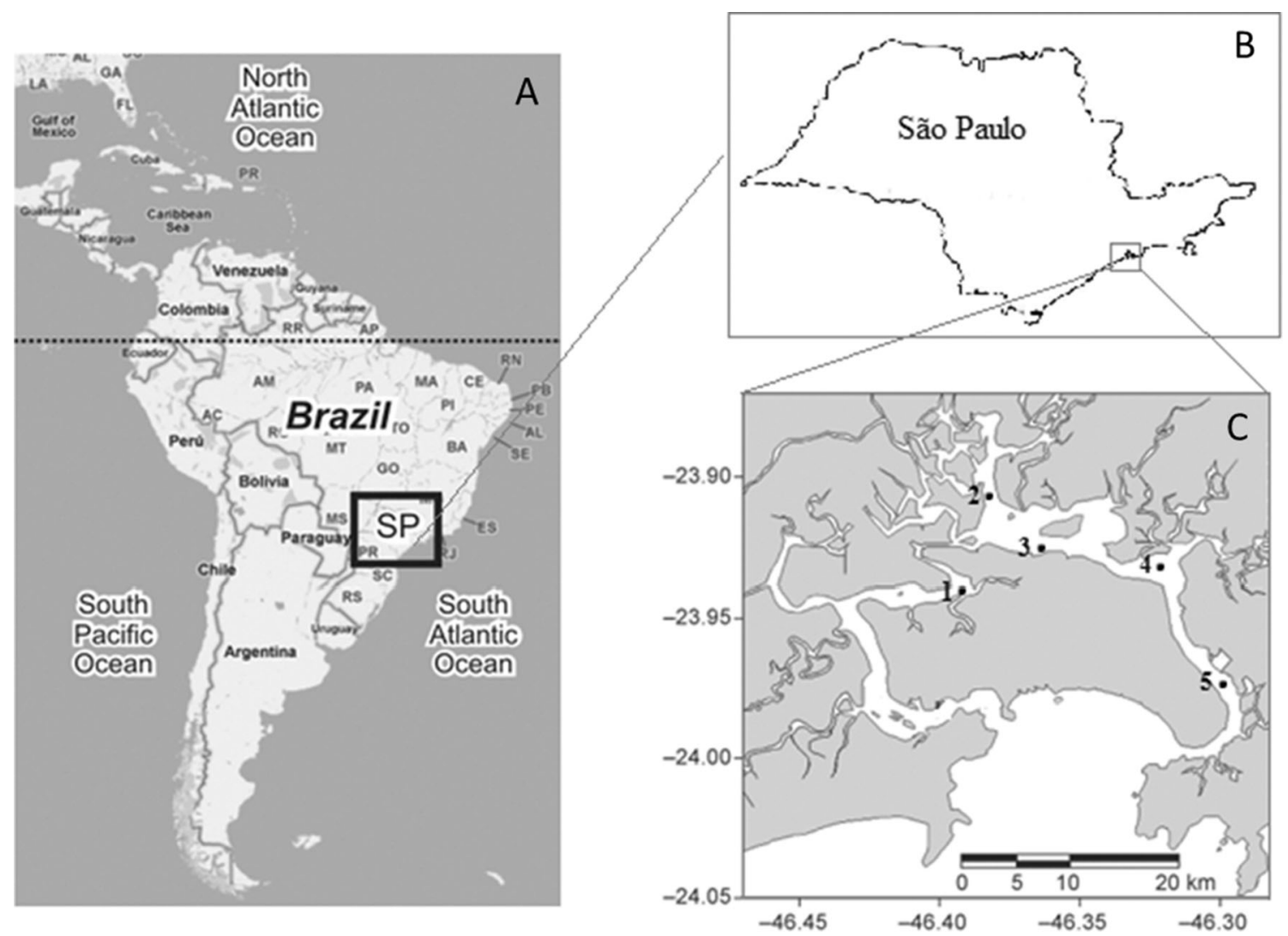

Fig. 1 Map of the study area located in Brazil (A). Port of Santos located at São Paulo State (B). In detail, location of the 5 stations where the sediment samples were collected (C) 
form of $\mathrm{Cr}_{2}\left(\mathrm{SO}_{4}\right)_{3}$ at concentrations of $0.4,4.0,7.0$, and 13 $\mathrm{mM}$. Zinc was used in the form of $\mathrm{ZnSO}_{4}$ at concentrations of $0.3,1.0,6.0$, and $10 \mathrm{mM}$. Each metal was tested separately.

The inoculum was prepared using the three sediment samples $(\sim 10 \mathrm{~mL}$ each) mixed and diluted in $40 \mathrm{~mL}$ of a $\mathrm{NaCl}$ anoxic solution $(0.9 \%(\mathrm{w} / \mathrm{v}))$. A $10 \% \mathrm{v} / \mathrm{v}$ of sediment slurry $(5 \mathrm{~mL}$ ) was added to the bottles with $45 \mathrm{~mL}$ of Postgate $\mathrm{C}$ medium, to a final volume of $50 \mathrm{~mL}$. A positive control with medium without metal addition and negative control (medium and metals without inoculum addition - the highest concentration used in each enrichment was used in the negative control, also to check spontaneous precipitation) was prepared. Enrichments were incubated statically in the dark at $30{ }^{\circ} \mathrm{C}$ for 35 days. All the experiments were performed in triplicates.

The SRB activity in each enrichment was monitored through weekly sulfate and sulfide measurements. Sulfate was measured using turbidimetric method (APHA 2012).

The total dissolved sulfide concentration was determined using the methylene blue method (APHA 2012) with the USEPA Methylene Blue Method kit (HACK®, USA) following the manufacturer's instructions. Sulfide was measured immediately after removing the sample from the enrichments.

The lactate and other organic acids produced in each bottle at the end of the experiment were measured through gas chromatography GC-2010 (Shimadzu Scientific Instruments Columbia, MD, USA) equipped with HP-INNOWAX column ( $30 \mathrm{~m}$ length $\times 0.25 \mathrm{~mm}$ inner diameter $\times 0.25 \mathrm{~mm}$ film thickness) and flame ionization detector (FID), using hydrogen as a carrier gas, according to the methodology described by Adorno et al. (2014). The concentration of dissolved metals was measured at the beginning and at the end of the experiment using a High-Resolution Continuum Source Atomic Absorption Spectrometer (model 300, Analytik Jena, HR-CS AAS).

\section{Microbial community analysis}

The sediment used as inoculum and $1 \mathrm{~mL}$ of each enrichment after incubation were taken for DNA extraction. DNA extraction was performed using a PowerSoil@ DNA Extraction Kit (MOBIO, USA), according to the manufacturer's instructions. A DNA purification kit Wizard ${ }^{\circledR}$ DNA Clean-Up System (Promega, USA) was used to reduce PCR inhibition.

DNA concentration was measured with a fluorimeter (Quibit ${ }^{\circledR} 2.0$ ). PCR was performed in triplicate at a total vol-

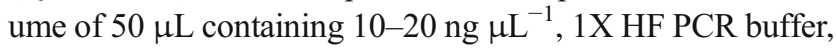

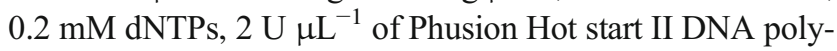
merase (Promega, Madison, WI), $10 \mu \mathrm{M}$ of primer 515F806R (Caporaso et al. 2011) with different barcodes for each

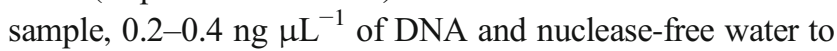
the final volume. The amplification program consisted of one step of denaturation at $98{ }^{\circ} \mathrm{C}$ for $30 \mathrm{~s}, 25$ cycles of denaturation at $98{ }^{\circ} \mathrm{C}$ for $10 \mathrm{~s}$, annealing at $56{ }^{\circ} \mathrm{C}$ for $10 \mathrm{~s}$, and elongation at $72{ }^{\circ} \mathrm{C}$ for $10 \mathrm{~s}$; and a final extension step at 72 ${ }^{\circ} \mathrm{C}$ for $7 \mathrm{~min}$.

The size of the PCR products was checked by gel electrophoresis on a $1 \%(\mathrm{w} / \mathrm{v})$ agarose gel containing $1 \mathrm{x}$ SYBR ${ }^{\circledR}$ Safe (Invitrogen, Carlsbad, CA). PCR products were purified using a HighPrep ${ }^{\text {TM }}$ PCR Clean-up System (MagBio Genomics Inc., USA). The purified PCR products were mixed in equimolar amounts with a DNA concentration of $100 \mathrm{ng}$ $\mu \mathrm{L}^{-1}$. The clustered amplicons were sequenced using FLX Genome Sequencing in combination with titanium chemistry (GATC-Biotech, Konstanz, Germany).

All sequence readings were processed by the NGS SILVA rRNA analysis pipeline (SILVAngs 1.0) (Pruesse et al. 2012). Identical readings were identified, and the exclusive readings were grouped into operational taxonomic units (OTUs), applying identity criteria of 0.98 . To obtain the taxonomic profiles, the generated sequences were submitted to computational analysis using the MOTHUR bioinformatics program (Schloss et al. 2009). The cluster analysis of bacterial communities was done using PAST4.01.

All data were submitted to the National Center for Biotechnology Information (NCBI) Sequence Read Archive (SRA) (https://submit.ncbi.nlm.nih.gov/subs/sra/) through BioProject number PRJNA531183.

\section{Isolation of metal-resistant SRB from the enrichments}

The enrichments with the highest metal concentrations that presented sulfate reduction activity were chosen as a source for the isolation process.

A solid media was made with the same composition of the media described before adding 13\% of Nobel Agar (SigmaAldrich), and distributed in petri dishes, using the anaerobic tent to preserve the anoxic conditions. One hundred microliter of the chosen enrichments was inoculated using the Spread plate technique. The plates were disposed in anaerobic jars pressurized with $\mathrm{N}_{2} / \mathrm{CO}_{2}(80: 20, \mathrm{v} / \mathrm{v})$ that were incubated for a maximum of 28 days at $30{ }^{\circ} \mathrm{C}$, or until colony growth was observed.

The colonies observed in solid media were inoculated in 15 $\mathrm{mL}$ liquid cultures with lactate, sulfate, and metals (with the same concentrations used in the previous enrichments), and without yeast extract to avoid fermenter contamination improving the purity and certifying that the colonies reduced sulfate in the presence of metals. At the end of the experiment, nine pure cultures were identified and analyzed.

\section{Identification and phylogenetic reconstruction}

Strain identifications were made through 16S rRNA gene sequencing using the Sanger sequencing technique. First, 1.0 $\mathrm{mL}$ of liquid culture was centrifuged for $5 \mathrm{~min}$ at $14,000 \mathrm{~g}$ and the supernatant was removed. After this process, the pellet 
was resuspended in $100 \mu \mathrm{L}$ of Tris- $\mathrm{HCl}$ buffer (T.E.). From this cell suspension, $2 \mu \mathrm{L}$ was used as template material for PCR using the 27F and 1492R primers (Timmers et al. 2015). The PCR product was examined by gel electrophoresis and cleaned using the MasterPure ${ }^{\circledR}$ DNA Purification Kit according to the manufacturer's instructions. DNA was sent to GATC Biotech (Konstanz, Germany) for Sanger sequencing using the same primers as sequencing primers. The partial sequences were quality trimmed, checked for vector contamination, and merged into full-length sequences with DNA Baser version 4.20.0. The resulting sequences were aligned and classified with SINA v1.2.11 (Pruesse et al. 2012) using the SILVA Ref NR SSU r128 database (Yilmaz et al. 2014).

\section{Genome sequencing}

For genome sequencing, the strain was grown in $100 \mathrm{~mL}$ cultures described previously for the isolation process. Biomass was collected by centrifugation at $4,700 \mathrm{~g}$ and $4{ }^{\circ} \mathrm{C}$ for $20 \mathrm{~min}$, after which the supernatant was discarded. To avoid contaminant that could interfere in the DNA extraction, two wash steps were carried out. The pellet was resuspended in sterile phosphate buffer, centrifuged at $13,400 \mathrm{~g}$ and $4{ }^{\circ} \mathrm{C}$ for $10 \mathrm{~min}$, and the supernatant was discarded again. This step was repeated twice. For a high quality and quantity DNA for a good genome sequence, the protocol described by Salvà-Serra et al. (2018) was used. The quality and concentration of genomic DNA were observed through electrophoresis gel, nanodrop, and with a fluorimeter (Quibit ${ }^{\circledR} 2.0$ ). Genomic DNA was frozen and sent to BaseClear BV (Leiden, The Netherlands) where sequencing was performed using the Illumina HiSeq2500 platform. The quality and duration of Illumina readings was inspected with FastQC, version 0.10 .12 .

The draft genomes were checked for completeness, contamination and strain heterogeneity with CheckM (Parks et al. 2015).

An analysis of the average nucleotide identity (ANI) between the genome dataset pairs was performed using the online ANI calculator tool, available at http://enve-omics.ce. gatech.edu/ani/index. DNA-DNA in silico (DDH) hybridization values were also determined using the Genome-toGenome Distance Calculator (GGDC), version 2.0 web server (Meier-Kolthoff et al. 2013).

\section{Results}

\section{Sediment characteristics}

The results of sediment characteristics are shown in Table 1 . The salinity ranges from 16.0 to 23.3 , the DO ranges from 37.7 to $69.7 \%$ and the percentage of OM changed in each station, being the lowest value of $1.6 \%$ at $\mathrm{P} 4$ and the highest $5.1 \%$ at $\mathrm{P} 5$. The lowest value of TOC percentage was $2.6 \%$ at $\mathrm{P} 2$ and the highest was $4.8 \%$ at P5.

The concentration found for each metal in each station is presented in Table 2. The cadmium concentrations were under detection limits in the sediments of all stations. Station P1 was the station with the highest metal concentration. Zinc was the metal found at the highest concentration, an average of $108 \mu \mathrm{g}$ $\mathrm{mg}^{-1}$.

\section{Enrichment analysis}

\section{Sulfate removal}

Tracking activity of the enrichments showed the effect of metal concentration on SRB activity (Fig. 2). Increasing metal concentrations had a progressive effect on both total sulfate removal and sulfate reduction rates. In the positive control without metals and in enrichments with $0.3 \mathrm{mM}$ of $\mathrm{Zn}$ and $0.4 \mathrm{mM}$ of $\mathrm{Cr}$, sulfate was completely consumed in an average of 28 days. The conditions with $\mathrm{Cr} 0.4 \mathrm{mM}$ and $\mathrm{Zn} 0.3 \mathrm{mM}$ presented higher sulfate removal rate than the positive control.

In the $\mathrm{Zn}$ enrichments, the microbial community was able to reduce $30 \mathrm{mM}$ and $21.9 \mathrm{mM}$ of sulfate at $\mathrm{Zn}$ concentrations of 0.3 and $1.0 \mathrm{mM}$, respectively. Remarkably, at the highest $\mathrm{Zn}$ concentration used in our enrichments $(10 \mathrm{mM}), 5 \mathrm{mM}$ of sulfate was reduced. In $\mathrm{Cr}$ enrichments, sulfate removal occurred in almost all of the $\mathrm{Cr}$ concentrations. In the lowest $\mathrm{Cr}$ concentration $(0.4 \mathrm{mM}), 30 \mathrm{mM}$ of sulfate was removed, and in the initial $\mathrm{Cr}$ concentrations of 4.0, 8, and $12 \mathrm{mM}, 12 \mathrm{mM}$ of sulfate was reduced.

The enrichments with different concentrations of $\mathrm{Cu}$ and $\mathrm{Cd}$ had a lower sulfate reduction, $10 \mathrm{mM}$ of sulfate was reduced in initial $\mathrm{Cd}$ concentration of $0.7 \mathrm{mM}$ and the amount reduced was progressively lower with an increase in $\mathrm{Cd}$ concentration. All enrichments with $\mathrm{Cu}$ reduced an average amount of $10 \mathrm{mM}$ of sulfate.

\section{Organic acids produced}

The amount of lactate and sulfate consumed, sulfide and acids produced, and metal removal in liquid phase at the end of the experiment are shown in Table 3.

SRB consume lactate, reduce sulfate, and produce sulfide that can precipitate metals according to Eqs. 1 and 2:

$$
\begin{aligned}
& 2 \mathrm{C}_{3} \mathrm{H}_{5} \mathrm{O} 3-+\mathrm{SO} 4-2 \rightarrow 2 \mathrm{CH} 3 \mathrm{COO}-+2 \mathrm{HCO}^{-}- \\
& \quad+\mathrm{HS}^{-}+\mathrm{H}+(\text { lactate })(\text { acetate }) \\
& H S+M \rightarrow M S(S)+H+
\end{aligned}
$$

Thus, having consumed the concentrations of lactate and sulfate, the number of organic acids produced through 
Table 1 Physicochemical data at 5 sampling stations during sample collection (dissolved oxygen (D.O.); organic matter (O.M.); total organic carbon (T.O.C))

\begin{tabular}{llllllll}
\hline & Depth $(\mathrm{m})$ & Temperature $\left({ }^{\circ} \mathrm{C}\right)$ & Salinity & D.O. $(\%)$ & $\mathrm{pH}$ & O.M. (\%) & T.O.C. (\%) \\
\hline P1 & 1.0 & 26.3 & 16.0 & 46.5 & 5.7 & 4.1 & 3.2 \\
P2 & 1.7 & 26.6 & 14.8 & 38.0 & 5.8 & 2.1 & 2.6 \\
P3 & 1.7 & 27.0 & 24.4 & 69.7 & 5.8 & 2.0 & 4.2 \\
P4 & 2.0 & 27.0 & 23.2 & 45.9 & 6.0 & 1.6 & 4.3 \\
P5 & 1.8 & 27.8 & 23.3 & 37.7 & 6.1 & 5.1 & 4.8 \\
\hline
\end{tabular}

sulfidogenesis could be calculated. In the positive control, the acetic and isolaveric acids detected were produced due to sulfidogenesis $(55.5 \mathrm{mM})$. In $\mathrm{Zn}$ enrichments, the acids produced due to sulfidogenesis were significantly lower in the bottles with $\mathrm{Zn}$ initial concentration of 6.0 and $10.0 \mathrm{mM}$.

The highest levels of dissolved sulfide detected were in the enrichments without metals (positive control), with initial $\mathrm{Zn}$ concentration of $0.3 \mathrm{mM}$ and $1.0 \mathrm{mM}, \mathrm{Cr} 0.4 \mathrm{mM}, \mathrm{Cd} 0.2$ $\mathrm{mM}$, and $\mathrm{Cu} 0.3 \mathrm{mM}$. Low concentrations of dissolved sulfide were detected in the other metal enrichments (Table 3).

At the end of the experiment, the highest metal concentration removal in liquid phase was $4.5 \mathrm{mM}$ of $\mathrm{Cu}, 5.4 \mathrm{mM}$ of $\mathrm{Zn}, 9.6 \mathrm{mM}$ of $\mathrm{Cr}$, and $0.2 \mathrm{mM}$ of $\mathrm{Cd}$.

Acetic acid and propionic acid were the main organic acids produced in the enrichments (Table 4). In the positive control, acetate represents almost all the organic acids produced (54.5 $\mathrm{mM}) . \mathrm{Cu}$ enrichments $(0.3,1.3$, and $3.3 \mathrm{mM})$ showed similar propionic acid production $(32.3-35 \mathrm{mM})$, higher than acetate concentration (16.3-22.2 mM). In Cd enrichments, higher concentrations of propionic acid as average ( $29.0 \mathrm{mM}$ ) were found when compared to the average amount of acetic acid detected ( $13.5 \mathrm{mM}$ ). $\mathrm{Zn}$ and $\mathrm{Cr}$ enrichments had similar proportions of organic acids produced. For the lowest metal concentrations tested, higher acetate productions were found in average (30.3-38.8 $\mathrm{mM}$ ), whereas higher concentrations of propionate were found in the bottles with higher metal concentrations

\section{Microbial community analysis}

The microbial community composition of the sediment slurry used as inoculum had approximately $9.3 \%$ of the sequences

Table 2 Metal concentrations ( $\mathrm{Zn}, \mathrm{Cr}, \mathrm{Cd}$, and $\mathrm{Cu}$ ) in $\mu \mathrm{g} \mathrm{mg}{ }^{-1}$ of sediment for each of the sampling stations

\begin{tabular}{lllll}
\hline & Zinc & Chromium & Copper & Cadmium \\
\hline P1 & $230 \pm 0.010$ & $24 \pm 0.000$ & $29 \pm 0.001$ & $<0.004$ \\
P2 & $144 \pm 0.003$ & $12 \pm 0.001$ & $8.7 \pm 0.000$ & $<0.004$ \\
P3 & $79 \pm 0.003$ & $22 \pm 0.001$ & $23 \pm 0.000$ & $<0.004$ \\
P4 & $60 \pm 0.001$ & $15 \pm 0.000$ & $13 \pm 0.001$ & $<0.004$ \\
P5 & $28 \pm 0.000$ & $13 \pm 0.001$ & $6.0 \pm 0.005$ & $<0.004$ \\
\hline
\end{tabular}

that belong to SRB genera. Desulfobulbus-related sequences presented the highest abundance ranging from 4.3 to $7 \%$ of the total sequence count. The other SRB sequences were assigned to Desulfatiglans (1.2\%) Desulfococcus (0.5\%), Desulfovibrio (0.3\%), and Desulfosarcina $(0.1 \%)$.

The microbial community found in the metal enrichments is shown in Fig. 3, highlighting the genus Desulfovibrio, the most abundant SRB. The positive control also showed other SRB as Dethiosulfovibrio and Thermodesulfovibrio. Desulfovibrio appeared in higher concentrations in the enrichments: $\mathrm{Cu}$ 0.3; $\mathrm{Cu}$ 1.3; $\mathrm{Cu}$ 3.0; $\mathrm{Cd} \mathrm{0.2;} \mathrm{Zn} \mathrm{0.3;} \mathrm{Zn} \mathrm{1.0.}$ Citrobacter was an important genus that appeared in enrichments with the highest metal concentration of $\mathrm{Cu}, \mathrm{Cr}$, and $\mathrm{Cd}$.

Up to $6 \mathrm{mM}$ zinc initial concentration, a significant number of sequences affiliated to the genera Desulfovibrio and Thermodesulfovibrio was not observed. At the highest concentration (Zn $10 \mathrm{mM}$ ), the presence of sulfate-reducing bacteria was not observed. Clostridium, Alkaliphilus, and Lactococcus were more abundant.

Sulfate-reducing bacteria were only found at $0.4 \mathrm{mM}$ concentration of $\mathrm{Cr}$, with sequences belonging to Desulfovibrio sp. and Desulfobulbus, and at the $4.0 \mathrm{mM}$ concentration where only the Desulfovibrio genus was found. At higher concentrations, there was dominance of Clostridium and Citrobacter.

In the cadmium enrichments, sequences belonging to Desulfovibrio were observed only in concentrations of $0.2 \mathrm{mM}$ and $0.3 \mathrm{mM}$. In the two highest concentrations, Clostridium, Citrobacter, and Vibrio dominance were predominant.

In copper enrichments, the only genus of sulfate-reducing bacteria found was Desulfovibrio, and the abundance ranges from 0.25 to 0.30 .

The similarity analysis (Fig. 4) among the microbial communities of the enrichments showed clustering by metal concentrations more than metal types. Within metal types, the communities present in the $\mathrm{Cd}$ and $\mathrm{Cu}$ enrichments were closer while the $\mathrm{Cr}$ and $\mathrm{Zn}$ enrichment communities were more similar.

\section{Isolation of metal-resistant SRB from the enrichments}

Seven different strains were isolated. The phylogenetic tree based on 16S rDNA is presented in Fig. 5. All the isolated strains were assigned as the same species. The closest relative 

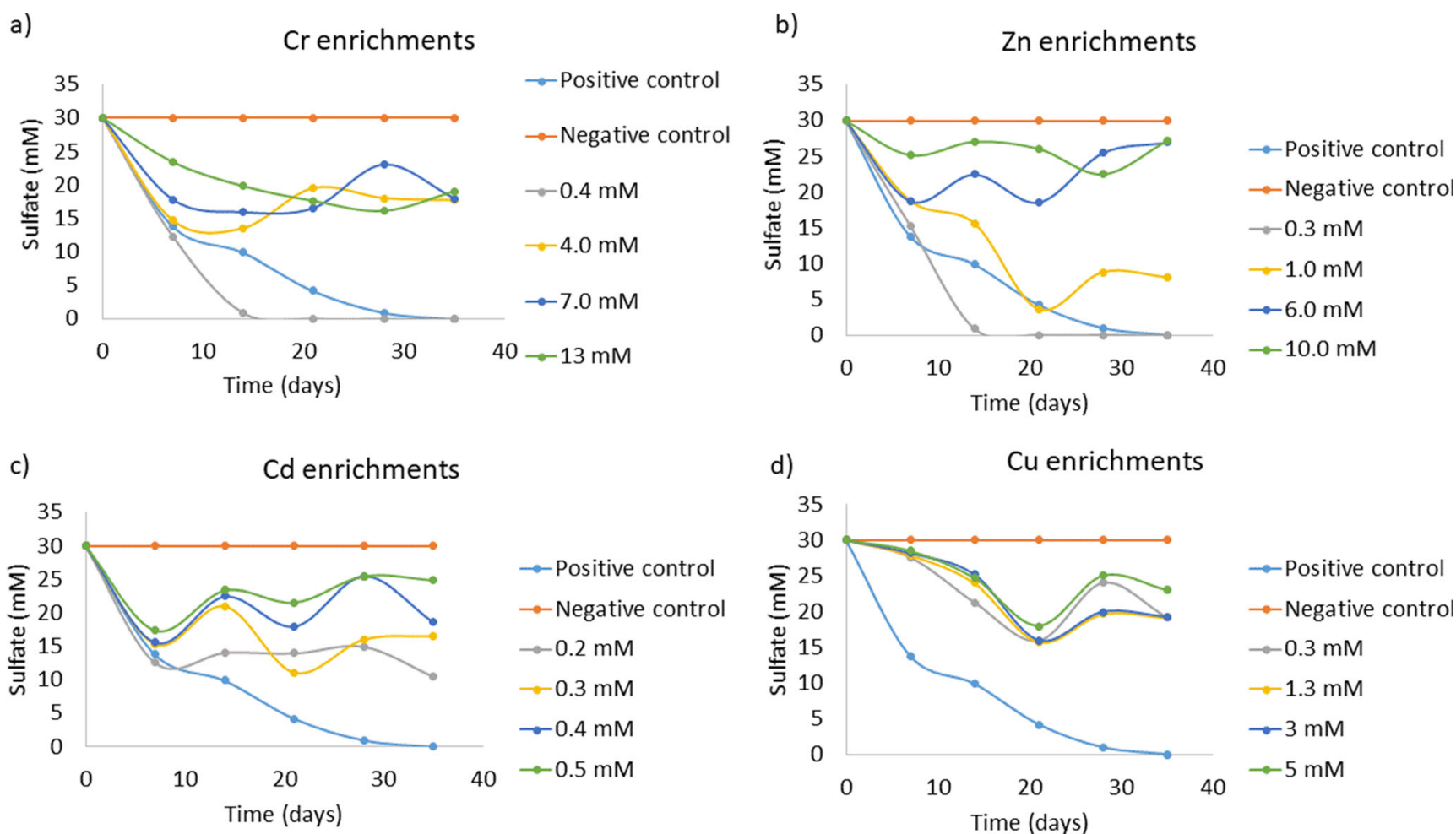

Fig. 2 Sulfate concentrations in enrichments with different concentrations of $\mathrm{Cr}(\mathbf{a}) ; \mathrm{Zn}(\mathbf{b}) ; \mathrm{Cd}(\mathbf{c}) ; \mathrm{Cu}$ (d) for 35 days

is Desulfovibrio desulfuricans. The similarity level indicates that the isolated strains were not the same as D. desulfuricans.
The percentage similarity between the isolates and the closest relatives can be seen in Table 5 .

Table 3 Values of lactate $(\mathrm{mM})$ and sulfate $(\mathrm{mM})$ consumed, dissolved sulfide $(\mathrm{mM})$, and organic acids produced in total and through sulfidogenesis $(\mathrm{mM})$, metal removal in liquid phase $(\mathrm{mM})$ in each enrichment after 35 days

\begin{tabular}{|c|c|c|c|c|c|c|}
\hline & $\begin{array}{l}\text { Lactate } \\
\text { consumed } \\
(\mathrm{mM})\end{array}$ & $\begin{array}{l}\text { Sulfate } \\
\text { consumed } \\
(\mathrm{mM})\end{array}$ & $\begin{array}{l}\text { Organic acids } \\
\text { produced }(\mathrm{mM})\end{array}$ & $\begin{array}{l}\text { Organic acids produced } \\
\text { through sulfidogenesis }(\mathrm{mM})\end{array}$ & $\begin{array}{l}\text { Dissolved sulfide } \\
\text { produced }(\mathrm{mM})\end{array}$ & $\begin{array}{l}\text { Metal removal in } \\
\text { liquid phase }(\mathrm{mM})\end{array}$ \\
\hline Negative control & 0 & 0 & 0 & 0 & 0 & 0 \\
\hline Positive control & 56.7 & 30 & 55.5 & 55.5 & 15 & - \\
\hline Cu 0.3 & 56.0 & 10.8 & 54.4 & 21.6 & 3.1 & 0.2 \\
\hline Cu 1.3 & 51.8 & 8.8 & 51.0 & 17.6 & 0.1 & 1.25 \\
\hline Cu 3.0 & 50.7 & 7.7 & 49.9 & 15.4 & 0.1 & 2.5 \\
\hline Cu 5.0 & 42.3 & 5 & 38.5 & 10 & 0.1 & 4.5 \\
\hline Zn 0.3 & 45.1 & 28.0 & 41 & 41 & 15 & 0.25 \\
\hline Zn 1.0 & 61.2 & 21.9 & 59.2 & 43.8 & 13 & 0.8 \\
\hline Zn 6.0 & 42.3 & 3 & 39.5 & 6 & 1.6 & 5.4 \\
\hline Zn 10.0 & 55.0 & 2.8 & 51.7 & 5.6 & 0.1 & 4 \\
\hline Cr 0.4 & 45.1 & 30 & 32.9 & 32.9 & 13 & 0.32 \\
\hline $\mathrm{Cr} 4.0$ & 30.2 & 12.3 & 24.8 & 24.8 & 0.65 & 3.2 \\
\hline Cr 7.0 & 28.1 & 10 & 27.2 & 27.2 & 0.1 & 6.5 \\
\hline Cr 13.0 & 27.1 & 9 & 22.9 & 22.9 & 0.4 & 9.6 \\
\hline Cd 0.2 & 41.0 & 19.5 & 40.4 & 40.4 & 3 & 0.16 \\
\hline Cd 0.3 & 59.8 & 13.5 & 58.8 & 27 & 1.9 & 0.2 \\
\hline Cd 0.4 & 43.0 & 11.4 & 41.9 & 22.8 & 0.4 & 0.3 \\
\hline Cd 0.5 & 47.8 & 5.1 & 46.5 & 10.2 & 0.6 & 0.1 \\
\hline
\end{tabular}


Table 4 Acids produced $(\mathrm{mM})$ in enrichments with different concentrations of $\mathrm{Zn}, \mathrm{Cr}, \mathrm{Cu}$, and $\mathrm{Cd}$

\begin{tabular}{|c|c|c|c|c|c|c|}
\hline Enrichments & $\begin{array}{l}\text { n-Buthanol } \\
(\mathrm{mM})\end{array}$ & $\begin{array}{l}\text { Acetic ac. } \\
(\mathrm{mM})\end{array}$ & $\begin{array}{l}\text { Propionic ac. } \\
(\mathrm{mM})\end{array}$ & $\begin{array}{l}\text { Butyric ac. } \\
(\mathrm{mM})\end{array}$ & $\begin{array}{l}\text { Isovaleric ac. } \\
(\mathrm{mM})\end{array}$ & $\begin{array}{l}\text { Sum of produced acids } \\
(\mathrm{mM})\end{array}$ \\
\hline Negative control & 0.0 & 0.0 & 0.0 & 0.0 & 0.0 & 0.0 \\
\hline Positive control & 0.0 & 54.5 & 0.0 & 0.0 & 1.0 & 55.5 \\
\hline Cu 0.3 & 0.0 & 22.2 & 32.3 & 0.0 & 0.0 & 54.5 \\
\hline Cu 1.3 & 0.0 & 16.8 & 35.0 & 0.0 & 0.0 & 51.8 \\
\hline Cu 3.0 & 0.0 & 16.3 & 33.6 & 0.0 & 0.0 & 49.9 \\
\hline Cu 5.0 & 0.0 & 4.1 & 34.4 & 0.0 & 0.0 & 38.5 \\
\hline Zn 0.3 & 0.0 & 38.8 & 1.6 & 0.0 & 0.6 & 41.0 \\
\hline Zn 1.0 & 0.0 & 38.8 & 15.9 & 0.0 & 6.5 & 61.2 \\
\hline Zn 6.0 & 0.0 & 15.9 & 23.5 & 0.1 & 0.0 & 39.5 \\
\hline Zn 10.0 & 0.0 & 17.2 & 34.4 & 0.0 & 0.0 & 51.7 \\
\hline Cr 0.4 & 0.0 & 40.3 & 2.6 & 0.0 & 0.0 & 42.9 \\
\hline Cr 4.0 & 0.0 & 32.4 & 2.4 & 0.0 & 0.0 & 34.8 \\
\hline Cr 7.0 & 0.0 & 3.9 & 13.4 & 10.9 & 0.0 & 28.2 \\
\hline Cr 13.0 & 0.0 & 2.3 & 13.2 & 7.4 & 0.0 & 22.9 \\
\hline Cd 0.2 & 0.0 & 17.1 & 23.3 & 0.0 & 0.0 & 40.4 \\
\hline Cd 0.3 & 0.0 & 17.3 & 41.0 & 0.0 & 0.5 & 58.8 \\
\hline Cd 0.4 & 0.0 & 9.5 & 26.1 & 6.3 & 0.0 & 41.9 \\
\hline Cd 0.5 & 2.3 & 10.0 & 25.9 & 8.3 & 0.0 & 46.5 \\
\hline
\end{tabular}

Percentages lower than $98 \%$ can indicate new species (Yarza et al. 2014).

The genome sequence was used to confirm the presence of a new Desulfovibrio species. Average nucleotide identity and in silico DDH values obtained from pairwise comparison of the available genome sequences of Desulfovibrio genus members are shown in Table 6. The values confirm Desulfovibrio sp. FE33 as a new species.

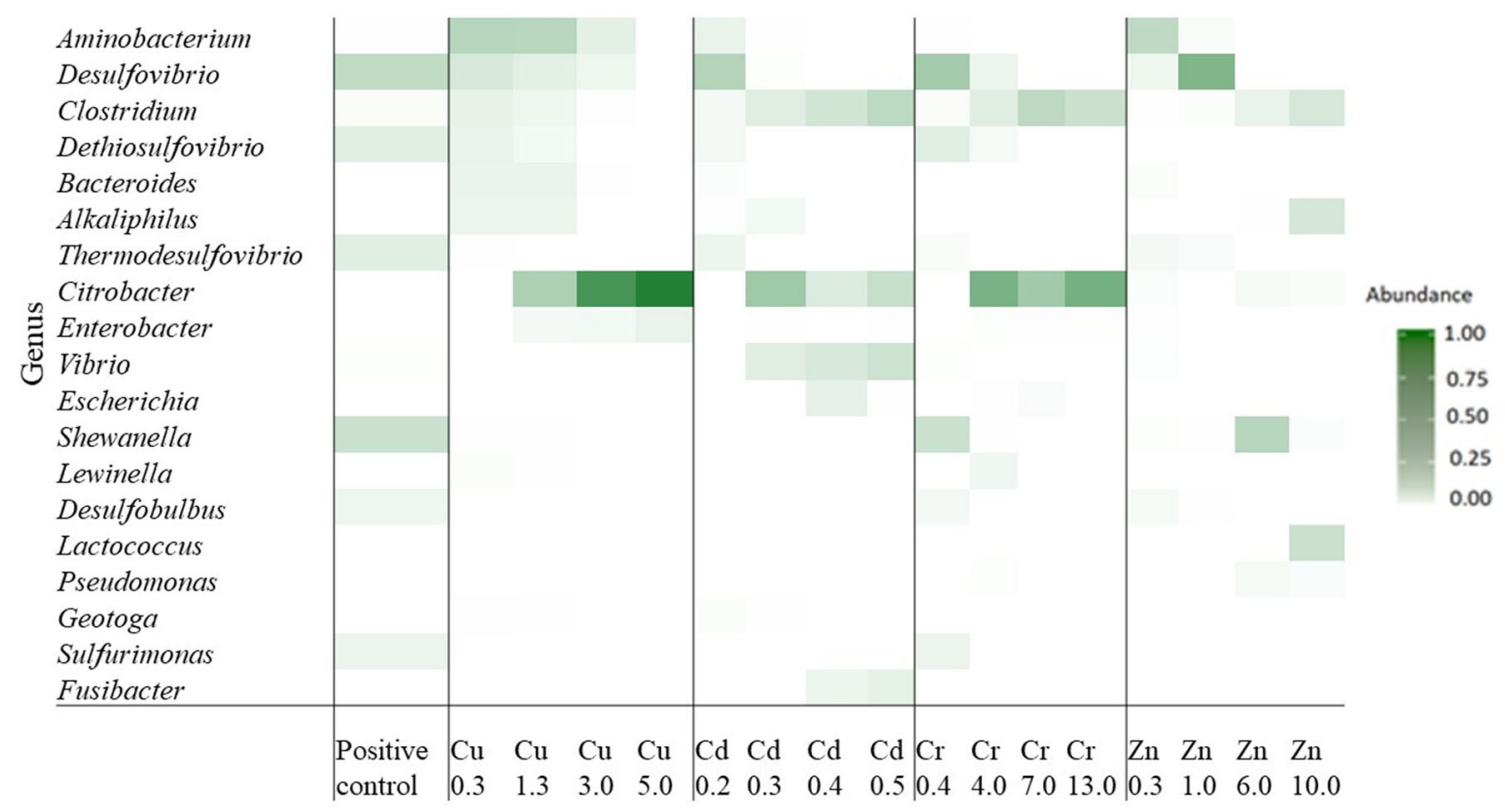

Enrichments

Fig. 3 Heat map reflecting the abundance of different genera identified in the samples of each enrichment. Dark green colors indicate higher abundance as reflected in the legend 
Fig. 4 Cluster analysis of bacterial communities found in different enrichments (in each triplicate) and in the sediment triplicates used as inoculum (sed 1 , sed 2, and sed3) based on the "Bray-Curtis" dissimilarity matrix.

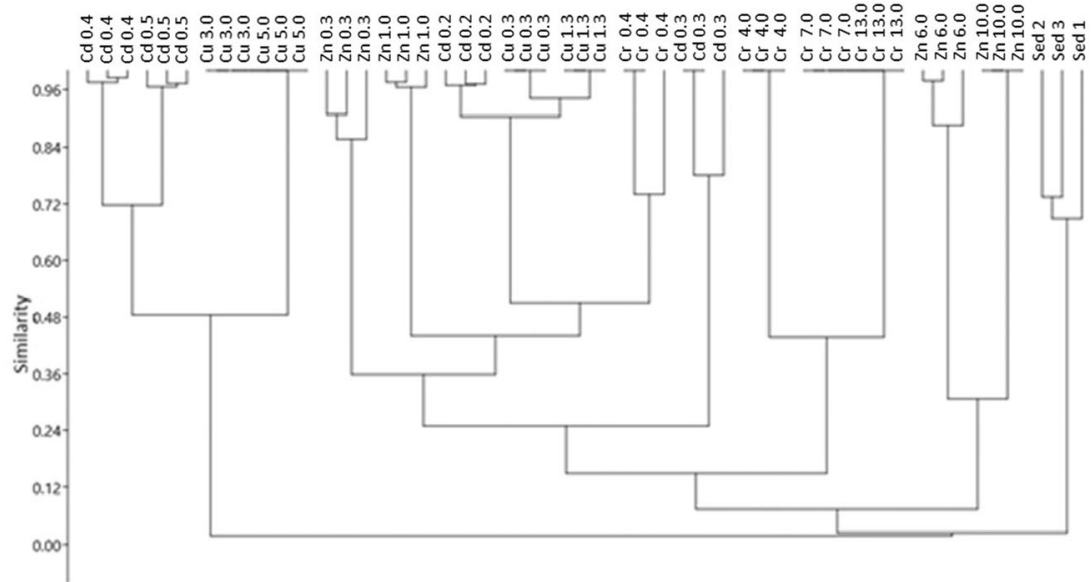

\section{Discussion}

Several studies have shown metal contamination in the port of Santos. According to Kim et al. (2015), the port of Santos is a good example of an environment that suffers from the continuous introduction of various contaminants.

Metal concentrations found in the sediment at the stations in the study area are considered safe for the biota according to the environmental agencies, which is $35.7 \mu \mathrm{g} \mathrm{g}^{-1}$ for $\mathrm{Cu}$, $37.3 \mu \mathrm{g} \mathrm{g}^{-1}$ for $\mathrm{Cr}, 0.6 \mu \mathrm{g} \mathrm{g}^{-1}$ for $\mathrm{Cd}$, and $123.1 \mu \mathrm{g} \mathrm{g}^{-1}$ for $\mathrm{Zn}$ (CCME 2002). However, there are many studies and reports that found metal concentrations above these limits at the Port of Santos (CETESB 2018; Kim et al. 2015; Buruaem et al. 2012). According to Buruaem et al. (2012), the proximity to the industrial sources is responsible for increasing the metal concentration; in some regions, the $\mathrm{Zn}$ concentration reached $1077 \mu \mathrm{g} \mathrm{g}^{-1}$ (Choueri et al. 2009) and $\mathrm{Cr}$ reached

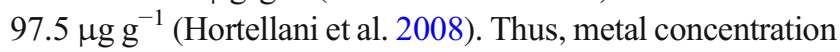
can vary along the port area in different stations and periods of time. This long-term exposure causes these microorganisms to tolerate high levels of metals as indicated by the enrichments. In addition, in the port sediment used as an inoculum, there was a large abundance of SRB that were exposed to metal contamination. The community present in the inoculum was able to reduce sulfate in very high metal concentrations.

Some studies demonstrate that one of the difficulties in applying SRB in reactors to treat contaminated waste is the high concentration of metals that is toxic and inhibits SRB activity (Zhang and Wang 2016; Ayangbenro et al. 2018). Other studies have demonstrated toxic metal concentrations

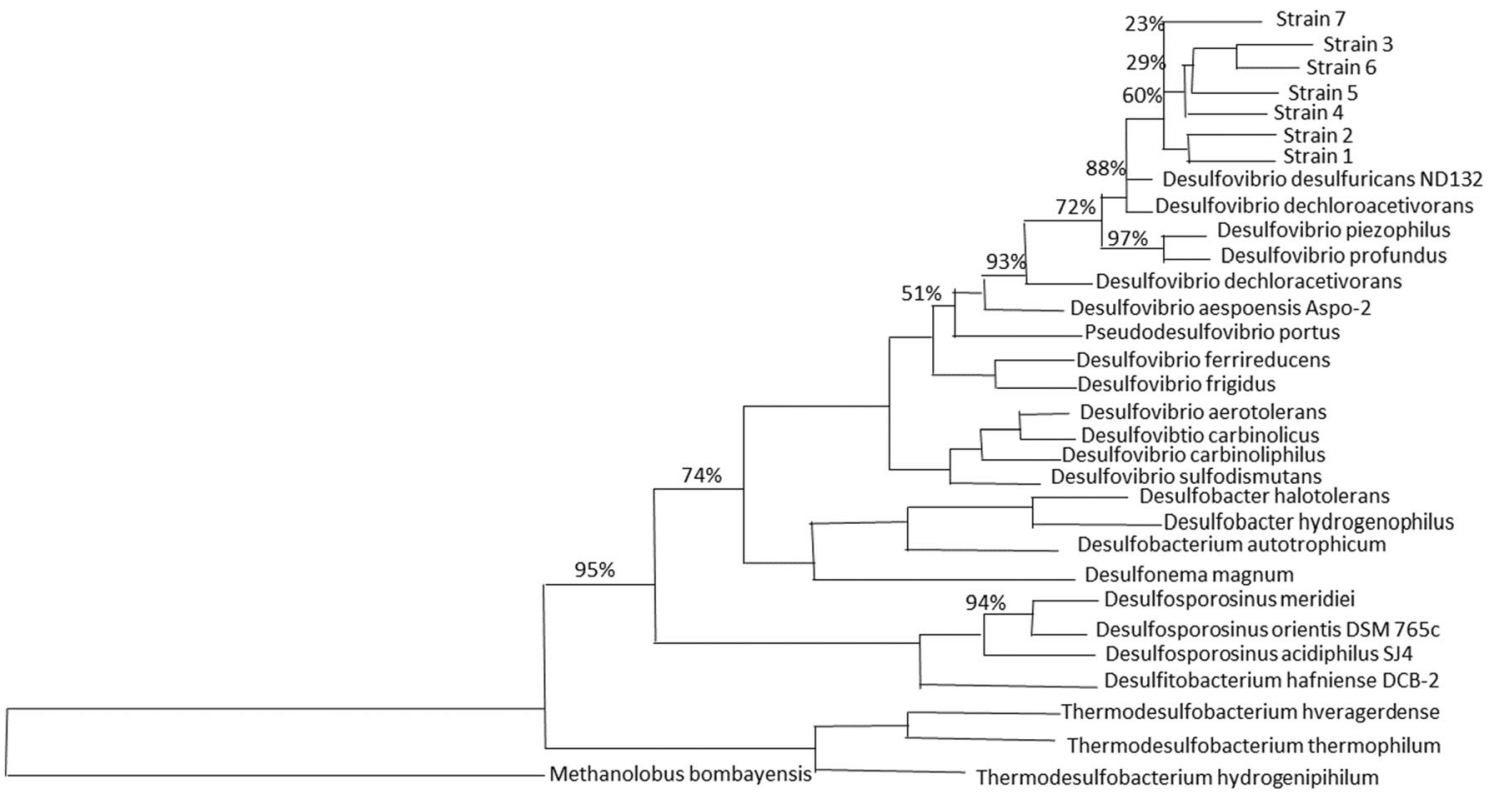

0.10

Fig. 5 Phylogenetic tree based on 16S rDNA sequence analysis, showing the phylogenetic placement of strains isolated in the present study. The tree was constructed by the neighbor-joining statistical method, and Methanolobus bombayensis was used as the out group 
Table 5 Similarity percentage by neighbor-Joining methods between the isolates (St1, St2, St3, St4, St5, St 6, and St 7) and the two closest relatives (Desulfovibrio desulfuricans (DsDesu) and Desulfovibrio dechloroacetivorans (DsDech))

\begin{tabular}{|c|c|c|c|c|c|c|c|c|c|}
\hline & St1 & St2 & St3 & St4 & $\mathrm{St} 5$ & St6 & St7 & DsDesu & DsDech \\
\hline St1 & - & 0.9916 & 0.9815 & 0.9863 & 0.9901 & 0.9923 & 0.9804 & 0.9760 & 0.9489 \\
\hline St2 & 0.9916 & - & 0.9875 & 0.9854 & 0.9886 & 0.9878 & 0.9791 & 0.9743 & 0.9468 \\
\hline St3 & 0.9863 & 0.9854 & - & 0.9812 & 0.9917 & 0.9939 & 0.9748 & 0.9640 & 0.9410 \\
\hline St4 & 0.9863 & 0.9854 & 0.9812 & - & 0.9894 & 0.9947 & 0.9770 & 0.9667 & 0.9416 \\
\hline St5 & 0.9901 & 0.9886 & 0.9917 & 0.9894 & - & 0.9931 & 0.9749 & 0.9750 & 0.9528 \\
\hline St6 & 0.9923 & 0.9878 & 0.9939 & 0.9947 & 0.9931 & - & 0.9762 & 0.9771 & 0.9550 \\
\hline St7 & 0.9804 & 0.9791 & 0.9748 & 0.9770 & 0.9749 & 0.9762 & - & 0.9679 & 0.9423 \\
\hline DsDesu & 0.9760 & 0.9743 & 0.9640 & 0.9667 & 0.9750 & 0.9771 & 0.9679 & - & 0.9622 \\
\hline DsDech & 0.9489 & 0.9468 & 0.9410 & 0.9416 & 0.9528 & 0.9555 & 0.9426 & 0.9622 & - \\
\hline
\end{tabular}

for SRB. Hao et al. (1994) observed inhibition of sulfate reduction in $0.32 \mathrm{mM}$ of $\mathrm{Cu}$ and $0.26 \mathrm{mM}$ of $\mathrm{Zn}$; Cabrera et al. (2006) observed inhibition of SRB activity in concentrations of $0.15 \mathrm{mM}$ of $\mathrm{Cu}, 0.13 \mathrm{mM}$ of $\mathrm{Zn}$; $\mathrm{Cd}$ in concentration of $0.12 \mathrm{mM}$ was toxic to SRB according to Binish et al. (2015); Guo et al. (2017b) observed inhibition of sulfate reduction in concentrations of $1.0 \mathrm{mM}$ of $\mathrm{Cr}$ and $0.8 \mathrm{mM}$ of $\mathrm{Zn}$. In the present study, SRB community was able to reduce sulfate in higher metal concentration $(\mathrm{Zn} 6.0 \mathrm{mM}, \mathrm{Cu} 3.0 \mathrm{mM}, \mathrm{Cd} 0.5$ $\mathrm{mM}$, and $\mathrm{Cr} 8.0 \mathrm{mM}$ ).

However, enrichments also demonstrated the impact of metals on SRB metabolism. The higher the concentration of metals, the less sulfate was removed (Fig. 2). Sheng et al. (2011) found similar patterns, when the initial concentration of $\mathrm{Cu}$ was higher than $0.3 \mathrm{mM}$, the sulfate concentration barely changed during the experiment, which indicates that SRB activity was completely inhibited. In the study of Guo et al. (2017b), when the concentrations of $\mathrm{Zn}^{-2}$ were below 0.2 $\mathrm{mM}$, the sulfate reduction efficiency was greater than $95.2 \%$, when $\mathrm{Zn}^{-2}$ concentration was increased to $1.5 \mathrm{mM}$, the efficiency decreased to $10 \%$.

In the present study, there was a removal of all the $30 \mathrm{mM}$ of sulfate added to the enrichments with an initial concentration of $\mathrm{Zn}$ of $0.3 \mathrm{mM}$ and $\mathrm{Cr} 0.4 \mathrm{mM}$. When the concentration of $\mathrm{Zn}$ was $1.0 \mathrm{mM}, 21.9 \mathrm{mM}$ of sulfate was reduced, which still demonstrates the community resistance. Whereas, Martins et al. (2009) showed that SRB were tolerant only at an initial concentration of $0.1 \mathrm{mM}$ of $\mathrm{Zn}$.

Table 6 Average nucleotide identity (ANI) and in silico DNA-DNA hybridization pairwise (DDH) comparison of Desulfovibrio sp. FE33 with the closest relative strains (Desulfovibrio desulfuricans)

\begin{tabular}{lll}
\hline & & \\
\hline DDH & 1 & 12.7 \\
& 2 & 20.0 \\
& 3 & 13.1 \\
\multirow{2}{*}{ ANI } & 4 & 83.8 \\
\hline
\end{tabular}

Higher sulfate removal rate was achieved in the medium containing $\mathrm{Zn}$ and $\mathrm{Cr}$. The higher removal rate was due to an intensive SRB activity, which reduces more sulfate, forming more sulfide that binds metal causing its precipitation. However, we cannot rule out other ways of removing metals, such as adsorption, especially considering their initial inoculum, or complexation with other compounds. According to Lin 1992 and Lin 1993, the sensitivity sequence of anaerobic processes to different metals is $\mathrm{Cd}>\mathrm{Cu}>\mathrm{Cr}>\mathrm{Zn}>\mathrm{Pb}>\mathrm{Ni}$. In the present study, a similar sequence was observed. The SRB in lower concentrations of $\mathrm{Cd}(0.2-0.5 \mathrm{mM})$ and $\mathrm{Cu}(0.3-5.0$ $\mathrm{mM})$ reduce less sulfate $(5.0-10.8 \mathrm{mM}$ and $5.1-19.5 \mathrm{mM}$, respectively) and precipitate less metal $(0.3$ and $4.5 \mathrm{mM}$, respectively) when compared to the enrichments with $\mathrm{Zn}(0.4$ $10 \mathrm{mM})$ and $\mathrm{Cr}(0.4-13.0 \mathrm{mM})$ that reduce more sulfate (3$30 \mathrm{mM}$ and 9-30 $\mathrm{mM}$, respectively) and precipitate more metals (5.6 mM and $9.9 \mathrm{mM}$, respectively).

This metal toxicity pattern was confirmed by analyzing the community present in the enrichments. The two more toxic metals $(\mathrm{Cd}$ and $\mathrm{Cu}$ ) had a greater community similarity with less SRB and more fermenters (e.g., Citrobacter and Clostridium). While the enrichments with less toxic metals for SRB ( $\mathrm{Cr}$ and $\mathrm{Zn}$ ) were closer by distance analysis, where the SRB genera (specially Desulfovibrio) were found in higher abundance. These results show us that these metals have similar influences on the SRB community, corroborated by previous studies that also showed higher $\mathrm{Cu}$ and $\mathrm{Cd}$ toxicity when compared to $\mathrm{Cr}$ and $\mathrm{Zn}$ (Cabrera et al. 2006; Ahmadi et al. 2015; Hussain and Qazi 2016). This noticeable difference in the impact of each metal on SRB metabolism, as well as the toxic concentrations of each metal, can help predict the behavior of this community in bioreactors during treatment of metal-contaminated effluents (Utgikar et al. 2003).

It is also important to highlight that the conditions with 0.4 $\mathrm{Cr}$ and $0.3 \mathrm{Zn}$ presented higher sulfate removal rate than the positive control. It indicates that these metals stimulate the SRB to some extent, and are toxic only in higher concentrations. This is corroborated by the heatmap that shows higher 
abundance of Desulfovibrio at conditions $0.4 \mathrm{mM} \mathrm{Cr}$ and $0.3 \mathrm{mM} \mathrm{Zn}$ than in the positive controls. Metals such as zinc and chromium are indispensable micronutrients for the growth and development of bacteria (Nies 1999). Several studies show that essential metal supplementation in a bioreactor may stimulate bacterial activity and optimize treatment process (Gustavsson et al. 2013; Schmidt et al. 2014; Gustavsson et al. 2011; Paulo et al. 2015).

It was clear that metals influence sulfate reduction metabolism. The higher the metal concentration, the lower sulfate reduction was observed. Where there was a higher metal concentration, the lactate was consumed through fermentation and not through sulfate reduction metabolism.

The metal influence on sulfate reduction metabolism can also be confirmed when the community present in the enrichments is analyzed. Figure 3 shows a drastic decrease in the SRB community, and consequently an increase in the proportion of fermentative bacteria (e.g., Citrobacter and Clostridium) when metals increase. In the fermentation process, these bacteria oxidize lactate mainly to propionate (Gonzalez-Garcia et al. 2017; Gänzle 2015; Vollenweider and Lacroix 2004). The lactate incomplete oxidation to acetate done by SRB through the sulfate reduction process was gradually replaced by the fermentation process due to the toxicity of the metals.

Citrobacter is a genus with a very versatile physiology, having the ability to grow through both aerobic and anaerobic mechanisms. Through anaerobic metabolism, it can degrade several carbon sources through respiration or fermentative metabolism. Under strict anoxic conditions, they can make complete oxidation of organic matter generating $\mathrm{CO}_{2}$ (Gerritse and Gottschal 1993; Brooks et al. 2015).

Several studies show the feasibility of using the genus Desulfovibrio for biotechnological applications (Zouch et al. 2017; Igiri et al. 2018). Kim et al. (2015) demonstrated the ability of the species Desulfovibrio desulfuricans to remove metals from seawater. The removal efficiency was $98.2 \%$, $99.8 \%$, and $90.1 \%$ for $\mathrm{Cu}^{2+}, \mathrm{Cr}^{6+}$, and $\mathrm{Ni}^{2+}$, respectively, after approximately 7 days.

A new Desulfovibrio species was isolated at the end of the study. In general, species of this genus can be applied to several contaminated effluent treatments (Sahinkaya et al. 2015; Kousi et al. 2015; Hussain et al. 2016). However, several studies demonstrate that its activity is restricted to certain initial concentrations of metals (Sani et al. 2003; Cabrera et al. 2006; Binish et al. 2015). Nevertheless, the new strain was isolated from an inoculum that was exposed to long-term metal contamination. This genus was found in enrichments with the following metal concentrations: $\mathrm{Zn} 6.0 \mathrm{mM}, \mathrm{Cu} 3.0 \mathrm{mM}$, $\mathrm{Cd} 0.3 \mathrm{mM}$, and $\mathrm{Cr} 7.0 \mathrm{mM}$. This is indicative of high metal resistance.

The long-term exposure to metals can favor the development of efficient resistance mechanisms. A study by Chen et al. (2019) demonstrated that areas, which have been exposed to the contamination of different metals $(\mathrm{Hg}, \mathrm{Pb}, \mathrm{Cu}$, $\mathrm{As}, \mathrm{Zn}, \mathrm{Cd}$, and $\mathrm{Cr}$ ) for a long time, presented a greater amount of resistance genes involved in the efflux of $\mathrm{Cu}, \mathrm{Zn}$, and $\mathrm{Cd}$ and mercury reduction.

Microorganisms are able to execute an array of metal resistance mechanisms to cope with metal toxicity by regulating intracellular metal concentrations in sublethal levels. These are (1) efflux of metals that enter cells by either specific or nonspecific transporters, (2) intracellular compartmentalization within safe sectors of cell reducing cytoplasmic availability of metals, (3) intra- or extracellular entrapment of metals by complexation with microbially generated ligands, and (4) enzymatic transformations reducing metal toxicity, etc. (Nies 1999; Sar et al. 2013).

\section{Conclusions}

Port areas are important sites for the study of metal-resistant and biotechnologically relevant sulfate-reducing bacteria. It was possible to notice that metals have a strong influence on SRB metabolism. Metals such as, zinc and chromium are indispensable micronutrients for bacterial growth, at low concentrations, stimulate the SRB, and are toxic only in higher concentrations. Essential metal supplementation in a bioreactor may stimulate bacterial activity and optimize treatment process.

Metals have different toxicities, affecting SRB activity at different ways. $\mathrm{Cd}$ and $\mathrm{Cu}$ were more toxics. The noticeable difference in the influence of each metal on SRB metabolism, as well as the toxic concentrations of each metal, can help predict the behavior of this community in bioreactors during treatment of metal contaminated effluents.

A new Desulfovibrio species was isolated in enrichments with high metal concentrations (Zn $6.0 \mathrm{mM}, \mathrm{Cu} 3.0 \mathrm{mM}, \mathrm{Cd}$ $0.3 \mathrm{mM}$, and $\mathrm{Cr} 7.0 \mathrm{mM}$ ). The new species was found in enrichments where higher concentrations of metals were present compared to the concentration of metals tolerated by other $\mathrm{SRB}$ species found in the literature. The isolation of SRBresistant strains can be very useful in future studies to optimize the metal removal from industrial waste to avoid that this type of pollutant reaches the environment. The environmental impact caused by metals and their detrimental effect on biota makes it urgent to seek efficient bioremediation treatment. Future studies to understand the resistance mechanisms present in this new species can also be very useful.

Supplementary Information The online version contains supplementary material available at https://doi.org/10.1007/s11356-021-15418-9.

Acknowledgements The authors would like to thank the Brazilian funding agency known as the Association for the Improvement of Higher Education Personnel (CAPES) for the fellowship. 
Author contribution Bruna Del Busso Zampieri, Gunther Brucha, and Irene Sánchez-Andrea designed the research. Oliveira AJF organized the sampling collection. Bruna Del Busso Zampieri performed sampling. Bruna Del Busso Zampieri and Elis Watanabe Nogueira performed experimental work. Bruna Del Busso Zampieri performed data analysis and wrote the manuscript with critical revision by Gunther Brucha, Irene Sánchez-Andrea, and Ana Julia Fernandes Cardoso de Oliveira with input from all authors.

Funding This research was financed in part by the Coordenação de Aperfeiçoamento de Pessoal de Nível Superior - Brasil (CAPES) Finance Code 001, fellowship no. 88882.434109/2019-01.

Availability of data and materials The metagenome data were submitted to the National Center for Biotechnology Information (NCBI) Sequence Read Archive (SRA) (https://submit.ncbi.nlm.nih.gov/subs/sra/) through BioProject number PRJNA531183. The rest of the datasets used and/or analyzed during the current study are available from the corresponding author on reasonable request.

\section{Declarations}

Ethics approval and consent to participate Not applicable

Consent for publication Not applicable

Competing interests The authors declare no competing interest.

\section{References}

Abessa DMS, Carr RS, Souza ECPM, Rachid BR, Zaroni LR, Gasparro M, Pinto YA, Bicero HMA, Sarkis JE, Muniz P (2008) Integrative ecotoxicological assessment of contaminated sediments in a complex tropical estuarine system. In: Hoffer TN (ed) Marine pollution: new research. Nova Science Publishers Inc, New York, pp 125-159

Adorno MAT, Hirasawa JS, Varesche MBA (2014) Development and validation of two methods to quantify volatile acids $\left(\mathrm{C}_{2}-\mathrm{C}_{6}\right)$ by $\mathrm{GC}-$ FID: headspace (automatic and manual) and liquid-liquid extraction (LLE). Am J Anal Chem 5:406-414

Ahmadi R, Rezaee A, Anvari M, Hossini H, Rastegar SO (2015) Optimization of $\mathrm{Cr}(\mathrm{VI})$ removal by sulfate-reducing bacteria using response surface methodology. Desalin Water Treat 57:1109611102. https://doi.org/10.1080/19443994.2015.1041055

Ali H, Khan E, Ilahi I (2019) Environmental chemistry and ecotoxicology of hazardous metals: environmental persistence, toxicity, and bioaccumulation. Journal of Chemistry 1:1-14. https://doi.org/10.1155/ 2019/6730305

APHA (2012) Standard methods for the examination of water and waste water, 22nd edn. American Public Health Association, American Water Works Association, Water Environment Federation

Argudín MA, Hoefer A, Butaye P (2019) Metal resistance in bacteria from animals. Res Vet Sci 122:132-147

Ayangbenro AS, Olanrewaju OS, Babalola OO (2018) Sulfate-reducing bacteria as an effective tool for sustainable acid mine bioremediation. Front Microbiol 9:1986. https://doi.org/10.3389/fmicb.2018. 01986

Azabou S, Mechichi T, Sayadi S (2007) Zinc precipitation by heavymetal tolerant sulfate-reducing bacteria enriched on phosphogypsum as a sulfate source. Min Eng 20:173-178. https://doi.org/10. 1016/j.mineng.2006.08.008
Bhattacharya SK, Uberoi V, Madura RL, Haghighi-Podeh MR (1995) Effect of cobalt on methanogenesis. Environ Technol 16:271-278. https://doi.org/10.1080/09593331608616269

Binish MB, Sruthy S, Mohan M (2015) Effect of metals (Pb, Cd, Cu) on the growth of sulphate reduction associated Bacterium Clostridium bifermentans isolated from Cochin estuary, Southwest coast of India. International Journal of Marine Science 5(50):1-5. https:// doi.org/10.5376/ijms.2015.05.0050

Brooks B, Mueller RS, Young JC, Morowitz MJ, Hettich RL, Banfield JF (2015) Strain-resolved microbial community proteomics reveals simultaneous aerobic and anaerobic function during gastrointestinal tract colonization of a preterm infant. Front Microbiol 6:654. https:// doi.org/10.3389/fmicb.2015.00654

Buruaem LM, Hortellani MA, Sarkis JE, Costa-Lotufo LV, Abessa DMS (2012) Contamination of port zone sediments by metals from Large Marine Ecosystems of Brazil. Mar Pollut Bull 64:479-488

Cabrera G, Perez R, Gomez JM, Abalos A, Cantero D (2006) Toxic effects of dissolved metals on Desulfovibrio vulgaris and Desulfovibrio $s p$. strains. J Hazard Mater 135:40-46

Caporaso JG, Lauber CL, Walters WA, Berg-Lyons D, Lozupone CA, Turnbaugh PJ, Fierer N, Knight R (2011) Global patterns of 16S rRNA diversity at a depth of millions of sequences per sample. Proc Natl Acad Sci U S A 108:4516-4522. https://doi.org/10.1073/pnas. 1000080107

CCME (2002) Canadian environmental quality guidelines, National Guidelines and Standards Office. Canadian Council of Ministers of the Environment, Winnipeg, $12 \mathrm{p}$

CETESB (2018) Companhia De Tecnologia De Saneamento Ambiental. Qualidade das águas costeiras no estado de São Paulo. Disponible at: https://cetesb.sp.gov.br/aguas-costeiras/wp-content/uploads/ sites/2/2018/06/Relat\%C3\%B3rio-de-Qualidade-das-\%C3\% 81 guas-Costeiras-do-Estado-de-S\%C3\%A3o-Paulo-2017.pdf; Acessed in: 13 de janeiro de 2020.

Chen J, Li J, Zhang H, Shi W, Liu Y (2019) Bacterial heavy-metal and antibiotic resistance genes in a copper tailing dam area in Northern China. Front Microbiol 10:1916

Choueri RB, Cesar A, Abessa DMS, Torres RJ, Morais RD, Riba I, Pereira CDS, Nascimento M, Mozeto AA, DelValls AT (2009) Development of site specific sediment quality guidelines for North and South Atlantic littoral zones: comparison against national and international sediment quality benchmarks. J Hazard Mater 170: 320-331

Fu F, Wang Q (2011) Removal of metal ions from wastewaters: a review. J Environ Manag 92:407-418. https://doi.org/10.1016/j.jenvman. 2010.11.011

Gänzle MG (2015) Lactic metabolism revisited: metabolism of lactic acid bacteria in food fermentations and food spoilage. Curr. Opin. Food Sci 2:106-117. https://doi.org/10.1016/j.cofs.2015.03.00

Gardner LR, Stewart PS (2002) Action of glutaraldehyde and nitrite against sulfate-reducing bacterial biofilms. J Ind Microbiol Biotechnol 29:354-360

Gaudette HE, Flight WR, Toner L, Folger DW (1974) An inexpensive tritation method for the determination of organic carbon in recent sediments. J Sediment Petrol 44:249-253

Gerritse J, Gottschal JC (1993) Two-membered mixed cultures of methanogenic and aerobic bacteria in O2-limited chemostats. J Gen Microbiol 139:1853-1860

Gillan DC, Roosa S, Kunath B, Billon G, Wattlez R (2015) The long-term adaptation of bacterial communities in metal-contaminated sediments: a metaproteogenomic study. Environ Microbiol 17:19912005

Gonzalez-Garcia RA, McCubbin T, Navone L, Stowers C, Nielsen LK, Marcellin E (2017) Microbial propionic acid production. Fermentation, $3: 3$ - 21.3. https://doi.org/10.3390/ fermentation 3020021 
Guo H, Nasir M, Lv J, Dai Y, Gao J (2017a) Understanding the variation of microbial community in metals contaminated soil using high throughput sequencing. Ecotoxicol Environ Saf 144:300-336. https://doi.org/10.1016/j.ecoenv.2017.06.048

Guo J, Kang Y, Feng Y (2017b) Bioassessment of metal toxicity and enhancement of metal removal by sulfate-reducing bacteria in the presence of zero valent iron. J Environ Manag 203:278-285. https:// doi.org/10.1016/j.jenvman.2017.07.075

Hao OJ, Huang L, Chen JM, Buglass RL (1994) Effects of metal additions on sulfate reduction activity in wastewaters. Toxicol Environ Chem 46:197-212. https://doi.org/10.1080/02772249409358113

Hortellani MA, Sarkis JES, Abessa DMS, Sousa ECPM (2008) Avaliação da contaminação por elementos metálicos dos sedimentos do estuário Santos - São Vicente. Quim Nova 31:10-19

$\mathrm{Hu} \mathrm{K}, \mathrm{Xu} \mathrm{D}$, Chen Y (2020) An assessment of sulfate reducing bacteria on treating sulfate-rich metal-laden wastewater from electroplating plant. J Hazard Mater 122376:122376. https://doi.org/10.1016/j. jhazmat.2020.122376

Hussain A, Qazi JI (2016) Metal-induced functional stress in sulphatereducing thermophiles. Biotech. 6:1-17. https://doi.org/10.1007/ s13205-015-0342-1

Igiri BE, Okoduwa SIR, Idoko GO, Akabuogu EP, Adeyi AO, Ejiogu IB (2018) Toxicity and bioremediation of metals contaminated ecosystem from Tannery Wastewater: a review. J Toxicol 2018:1-16. https://doi.org/10.1155/2018/2568038

Imchen M, Kumavath R, Barh D, Vaz A, Góes-Neto A, Tiwari S, Ghosh P, Wattam AR, Azevedo V (2018) Comparative mangrove metagenome reveals global prevalence of metals and antibiotic resistome across different ecosystems. Sci Rep 8:1-15

Jiménez EI, Garcia VP (1992) Relationships between organic carbon and total organic matter in municipal solid wastes and city refuse composts. Bioresour Technol 41:265-272

Jørgensen BB (1982) Mineralization of organic matter in the sea bed-the role of sulphate reduction. Nature 296:643-645. https://doi.org/10. $1038 / 296643 \mathrm{a} 0$

Kim H, Choi J, Joo JO, Kim Y, Choi J, Oh B (2015) Research Article Review jmb Development of a microbe-zeolite carrier for the effective elimination of metals from seawater. J Microbiol Biotechnol 25: 1542-1546. https://doi.org/10.4014/jmb.1504.04067

Kousi P, Remoundaki E, Hatzikioseyian A, Tsezos M (2015) Sulphatereducing bioreactors: current practices and perspectives, in Proceedings of the IWA Balkan Young Water Professionals 2015 (Thessaloniki: International Water Association), 409-417.

Lin CY (1992) Effect of metals on volatile fatty acid degradation in anaerobic digestion. Water Res 26:177-183

Lin CY (1993) Effect of metals on acidogenesis in anaerobic digestion. Water Res 27:147-152

Luptakova A, Kusnierova M (2005) Bioremediation of acid mine drainage contaminated by SRB. Hydrometallurgy 77:97-102

Martins M, Faleiro ML, Veríssimo AR, Barreiros MA, Costa MC (2009) Characterization and activity studies of highly metal resistant sulphate-reducing bacteria to be used in acid mine drainage decontamination. J Hazard Mater 166:706-713

Masindi V, Muedi KL (2018) Environmental contamination by metals. Metals. https://doi.org/10.5772/intechopen.76082

Muyzer G, Stams AJ (2008) The ecology and biotechnology of sulphatereducing bacteria. Nat Rev Microbiol 6:441-454. https://doi.org/10. 1038/nrmicro1892

Navarro EMG, Tagle MEV, Marín MTL, Alfonso MSP (2011) Comparison of USEPA 3050B and ISO 14869-1:2001 digestion methods for sediment analysis by using FAAS and ICP-OES quantification techniques. Quím Nova 34:1443-1449. https://doi.org/10. 1590/S0100-40422011000800025

Nies DH (1999) Microbial heavy-metal resistance. Appl Microbiol Biotechnol 51:730-750
Paulo LM, Stams AJM, Sousa DZ (2015) Methanogens, sulphate and metals: a complex system. Rev Environ Sci Biotechnol 14:537553. https://doi.org/10.1007/s11157-015-9387-1

Pinto AB, Pagnocca FC, Pinheiro MAA, Fontes RFC, Oliveira AJFC (2015) Metals and TPH effects on microbial abundance and diversity in two estuarine areas of the southern-central coast of São Paulo State, Brazil. Mar Pollut Bull 96:410-417. https://doi.org/10.1016/j. marpolbul.2015.04.014

Pruesse E, Peplies J, Glöckner FO (2012) SINA: accurate highthroughput multiple sequence alignment of ribosomal RNA genes. Bioinformatics 28:1823-1829. https://doi.org/10.1093/ bioinformatics/bts 252

Sahinkaya E, Yurtsever A, Toker Y, Elcik H, Cakmaci M, Kaksonenc AH (2015) Biotreatment of As-containing simulated acid mine drainage using laboratory scale sulfate reducing upflow anaerobic sludge blanket reactor. Miner Eng 75:133-139

Sancey B, Trunfio G, Charles J, Minary JF, Gavoille S, Badot PM, Crini G (2011) Metal removal from industrial effluents by sorption on cross-linked starch: chemical study and impact on water toxicity. J Environ Manag 92:765-772. https://doi.org/10.1016/j.jenvman. 2010.10.033

Sani RK, Peyton BM, Jadhyala M (2003) Toxicity of lead in aqueous medium to Desulfovibrio desulfuricans G20. Environ Toxicol Chem 22:252-260. https://doi.org/10.1897/1551-5028(2003)

Sar P, Kazy SK, Paul D, Sarkar A (2013) Metal bioremediation by thermophilic microorganisms. In: Satyanarayana T, Littlechild J, Kawarabayasi Y (eds) Thermophilic microbes in environmental and industrial biotechnology. Springer, Dordrecht. https://doi.org/ 10.1007/978-94-007-5899-5 6

Sarioglu M, Akkoyun S, Bisgin T (2010) Inhibition effects of metals (copper, nickel, zinc, lead) on anaerobic sludge. Desalin Water Treat 23:55-60. https://doi.org/10.5004/dwt.2010.1950

Schloss PD, Westcott SL, Ryabin T, Hall JR, Hartmann M, Hollister EB, Lesniewski RA, Oakley BB, Parks DH, Robinson CJ, Sahl JW, Stres B, Thallinger GG, Horn DJV, Weber CF (2009) Introducing mothur: open-source, platform-independent, community-supported software for describing and comparing microbial communities. ApplEnviron Microbiol 75:7537-7541

Sheng Y, Cao H, Li Y, Zhang Y (2011) Effects of sulfide on sulfate reducing bacteria in response to $\mathrm{Cu}(\mathrm{II}), \mathrm{Hg}(\mathrm{II})$ and $\mathrm{Cr}(\mathrm{VI})$ toxicity. Chin Sci Bull 56:862-868. https://doi.org/10.1007/s11434-0114397-z

Ture M, Altinok I, Alp H (2018) Effects of cage farming on antimicrobial and metal resistance of Escherichia coli, Enterococcus faecium, and Lactococcus garvieae. Microb Drug Resist 24(9):1422-1430. https://doi.org/10.1089/mdr.2018.0040

USEPA (United States Environmental Protection Agency) (1994) Method 3051. Microwave assisted acid digestion of sediments, sludges. Soils and oilsl. Revision 0. September.

Utgikar VP, Tabak HH, Haines JR, Govind R (2003) Quantification of toxic and inhibitory impact of copper and zinc on mixed cultures of sulfate-reducing bacteria. Biotechnol Bioeng 82:306-312. https:// doi.org/10.1002/bit.10575

Vollenweider S, Lacroix C (2004) 3-hydroxypropionaldehyde: applications and perspectives of biotechnological production. Appl Microbiol Biotechnol 64:16-27. https://doi.org/10.1007/s00253003-1497-y

Wieczorek-Dąbrowska W, Tomza-Marciniak A, Pilarczyk B, BalickaRamisz A (2013) Roe and red deer as bioindicators of metals contamination in north-western Poland. Chem Ecol 29:100-110

Yarza P, Yilmaz P, Pruesse E, Glockner FO, Ludwig W, Scheifer K, Whitman WB, Euzeby J, Amann R, Rosseló-Móra R (2014) Uniting the classification of cultured and uncultured bacteria and achaea using 16S rRNA gene sequences. Nature reviews 12:635645 
Yilmaz P, Parfrey LW, Yarza P, Gerken J, Pruesse E, Quast C, Schweer T, Peplies J, Ludwig W, Glöckner FO (2014) The SILVA and "Allspecies Living Tree Project (LTP)" taxonomic frameworks. Nucleic Acids Res 42:643-648. https://doi.org/10.1093/nar/gkt1209

Zayed G, Winter J (2000) Inhibition of methane production from whey by metals - protective effect of sulfide. Appl Microbiol Biotechnol 53: 726-731. https://doi.org/10.1007/s002530000336

Zhang W, Wang H (2016) Preparation of immobilized sulfate reducing bacteria (SRB) granules for effective bioremediation of acid mine drainage and bacterial community analysis. Miner Eng 92:63-71

Zhang L, Lin X, Wang J, Jiang F, Wei L, Chen G, Hao X (2016) Effects of Lead and Mercury on Sulfate-Reducing Bacterial Activity in a
Biological Process for Flue Gas Desulfurization Wastewater Treatment. Sci Rep 6(1). https://doi.org/10.1038/srep30455

Zouch H, Karray F, Armougom F, Chifflet S, Hirschker-Réa A, Kharrat H, Kamoun L, Hania WB, Ollivier B, Sayadi S, Quéméneur M (2017) Microbial diversity in sulfate-reducing marine sediment enrichment cultures associated with anaerobic biotransformation of coastal stockpiled phosphogypsum (Sfax, Tunisia). Front Microbiol 8:1583. https://doi.org/10.3389/fmicb.2017.01583

Publisher's note Springer Nature remains neutral with regard to jurisdictional claims in published maps and institutional affiliations. 